\title{
The Subversive Use of Parading Effeminacy by Transgender People in increasing Crime Rate in Bangladesh: A Study on Several Investigating Crime Reports
}

\author{
Sakina Akter Sema ${ }^{1} *$ \\ ${ }^{1}$ Department of English, Pundra University of Science and Technology, Bogura, Bangladesh. \\ *Correspondence: $\underline{\text { sakinaseema40@gmail.com }}$
}

\begin{abstract}
Transgender or Hijras are human being those who born with sexual deformation. They are considered as nor man nor women but the other third gender known as 'Hijras' in Indian-subcontinent. They have different societies that are lead by their leaders known as Guruma. They are strictly controlled by their gurumas and have very limited scope to enroll them in several activities without their permission. So frequently they are influenced by their gurumas to involve in criminal activities and sometimes they do that willingly for the other reasons. This study was an attempt to investigate the reasons for doing such criminal activities by them and to find the effects of such criminal activities in increasing crime rate in Bangladesh. To conduct this study a descriptive research design with qualitative study was applied. Most of the data was collected from secondary sources likescholarly articles, newspapers, several online YouTube channels, FBI reports, Bangladesh Police Discipline Security Progress reports and so on. Few data was also collected from primary sources like- directly interviewing the transgender people who have sufficient knowledge about criminal activities that are occurring at present time in Bangladesh. In case of interviewing, purposive sampling method was used to select the transgender people as sample size. The study has found that a number of criminal activities are done by the transgender people in Bangladesh and there are some reasons behind it. If the respective authorities take some necessary steps to reduce the causes then the effects will be ultimately reduced. Finally the total scenario of crime situation in Bangladesh will be changed positively and it would be a good place to live in for all regardless their gender identity.
\end{abstract}

Keywords: Transgender, Effeminacy, Crime, Crime rate, Subversive, Parading, and Bangladesh

\section{INTRODUCTION:}

A landmark decision has made by the Bangladesh government in November 11, 2013 through acknowledging the Hijras as third gender with the others two and this recognition secures their rights, enabling them to identify their gender as 'Hijra' in all government and non-government documents, including passports and others. This tremendous decision will allow them to identify their gender as 'Hijra' when their personal information needs to be furnished.

The cabinet secretary noted the community was "being denied their rights in various sectors, including education, health and housing because of being a marginal group (Ahmed, 2017). In Bangladesh, as third gender hijras have created a new identity of them. Their life leading style is totally different from 
others. There are dissimilarities between their livelihood and mainstream context of the society. They have limitations regarding culture, behavior and religious celebrations though they have gotten their recognition as third gender. So only official recognition is not enough for them to change the society but they need to give some scope to involve them in different activities that contribute to change the society as well as the country.

It is true that, Bangladesh is an emerging country in South-Asian context which continuing its GDP growth rate more than 7 percent indicates its overall development in all aspects but we can't ignore that at the same time the crime rate is also increasing. It will clear to us when we see the news reports from the various sources like- Radio, TV and Newspapers, etc (Parvez et al., 2019). The crime or offensive activities are intensified when we see that our marginalized people like- hijra community is also involving such criminal or offensive activities by using their parading effeminacy. Since they are different for their behaviors from the mainstream society, so they try to use their behaviors as their weapons' to do such criminal activities. But the surprising fact is that maximum time they are not doing such activities willingly but by pressure from gurus or others who are controlling them and get benefitted by their criminal activities. By doing such offensive activities they are paralyzing the economy and social strength of the country but uplifting the rank of the country in world crime index records. That is why, if the reasons can be identified properly and take necessary steps to stop doing such criminal activities then the society will be changed with stabilizing the marginalized group of people and finally the world would be a good place to live in peacefully (Hossain et al., 2019).

Primarily, this study was an attempt to investigate the articles and reports regarding criminal activities by the transgender people and their bosses to seek the answer of the questions that, what are the effects of the subversive use of parading effeminacy by transgender people in increasing crime rate in Bangladesh? Secondly, the study was to find the reasons behind their involvement in such criminal activities that is

UniversePG I www.universepg.com why the respective authorities can take proper steps to mitigate the problems to change the society.

\section{Background of the Study:}

Transgender is a case of mystery not only in this country but all over the world. The transgender people in Bangladesh are commonly known as 'Hijra'. From the very beginning of the history they are leading a different life, differentiated from the common people. They might have left their family and went with the other transgender people leaving behind their all possessions, rights, expectations to have a normal life. But when they enter into a new society that is different from the normal society they are being frustrated and feel discomfort to lead a normal life. As a result they are usually involved in various criminal or offensive activities like- prostitution, drug addiction, drug trafficking, fraud, black marketing, extortion and various others. The researcher thought these sorts of offensive activities instigate the crime rate in Bangladesh when the rank of Bangladesh is $12^{\text {th }}$ in the world Crime Index for 2019 report (Crime Index, 2019). In order to explore that issue this research has been formed. This study is very important in the perspective of our country as to find the contemporary picture of transgender people in other countries.

\section{Research Questions:}

It is said that, Bangladesh is an emerging country in South-Asian region which growing very rapidly with all political/legal, social, technological or economical aspects. Here, the gender discrimination rate is also decreasing very rapidly. At present all are being considered equal regardless their gender identity even though they are Transgender or Hijra people. Now they are being involved in different social and economic activities. But the question is that, they are being involved only such social and economic activities or they are also being involved in such criminal or offensive activities that are so harmful for the society? This study was attempts to find the truth of the statement and get the suggestions how the problems can be mitigate to safe the society.

\section{Objective of the Study:}

There are several works have been done on the two specific issues like- Transgender in Bangladesh and 
Crime Rate in Bangladesh but a very little on the two issues combined towards Bangladesh perspective. The main objective of the study is to explore the effects of the subversive use of parading effeminacy by transgender people in increasing crime rate in Bangladesh by considering several investigating crime reports that are recorded. The partial objective of the study is to find the reasons behind their involvement in such criminal activities that is why the respective authorities can take proper steps to mitigate the problems to change the society.

\section{Literature Review:}

The study reviews several theories related to the topics as well as empirical evidence from the different newspapers, periodicals, online news portals, research papers and publications captured herewith.

a. Theoretical Review: This section basically focused on theories that anchor the study in terms of variables.

\section{Transgender}

In our daily life we face various persons. Some of them seem to us surprising looking. They are neither man nor women in nature but they are the human being. In society they are popularly known as Transgender and in Indian subcontinent they are so called 'Hijra' people. Transgender people have a gender identity or gender expression that differs from their assigned sex (Altilio \& Otis-Green, 2011).

Transgender - often shortened as trans - is also an umbrella term that includes people whose gender identity is the opposite of their assigned sex (trans men and trans women), it may include people who are not exclusively masculine or feminine (people who are non- binary or gender queer, including bigender, pangender, gender fluid, or agender) (Forsyth \& Copes, 2014).

\section{Transgender in Bangladesh}

At present the cultural status of Hijras is now recognized as a specialist category 'third gender' on Bangladeshi national voters list by the government officials. Previously, the hijra community allowed applying their voting rights by signing up as men or women as a result many of them were not motivated and avoided doing so because they did not feel adequately represented. With the passes of time now transgender people can register to vote using their own identity as a hijra (Wallen, 2019). As per the government estimates there are around 10,000 hijras in Bangladesh although the other organizations those are working with hijras like- Bandhan Hijra Songha, a transgender rights group, etc. saying their number could be around 100,000.

\section{Crime}

Simply a crime is an unlawful act that is punishable by a state or other authority (Oxford English dictionary, 2009). The term "crime" does not, in modern criminal law, have any simple and globally accepted definition though statutory definitions have been provided for certain purposes. The most popular view about crime is that it is a category originated by law; in other words, something is a crime if declared as such by the relevant and applicable law (Farmer, 2008). One proposed definition is that a crime or offence (or criminal offence) is an act that is harmful not only to some individuals but also to a community, society, or the state or the country (a public wrong). Such criminal acts are forbidden and punishable by law (Elizabeth, 2003).

\section{Hate Crime}

A hate crime is defined as "any criminal or offensive activities which is perceived by the victim or any other person, to be influenced by a hostility or prejudice" based on one of five categories: religion, faith or belief; race, ethnicity or nationality; sexual orientation; disability; or gender identity. Presently transgender hate crimes recorded by police go up to $81 \%$ (BBC NEWS, 2019).

\section{Crime in Bangladesh}

Crime in Bangladesh is present in various forms like Drug trafficking, money laundering, political violence, Extortion, Contract killing, Fraud, Human trafficking, Robbery, Corruption, Black marketing, Terrorism and Abduction among others (Wikipedia, 2019). Though the crime rate in all over the world is increasing but in case of Bangladesh it is little bit more. As per the 
statistics of NUMBEO at present the position of Bangladesh is $12^{\text {th }}$ in Crime Index for country 2019 midyear with securing crime index points as 64.98 and safety index points as 35.02 (Crime Index, 2019).

In spite of legal, social, psychological and penal measures have taken for combating crime; the problem still persists in alarming rate. With the passes of time, new ways of crimes are coming up and the traditional ways of crimes are vanishing fast. The advancement in knowledge of human behavior and growth of commerce and industries has brought in their wake new complexities in life. These sorts of complexities accounted for the rising incidence of criminality. It is therefore apparent that crime. There is no reason to be upset with the present increase in crime rate. Nor should it create a misleading impresssion that the penal programmers have totally failed or proved ineffective. It must be stated that criminality in Bangladesh is going up but still less than in many other countries of the world and it is high time to control over such criminal activities. To do this there are no options but to retain the virtues of the mutual respect, tolerance and coexistence through its several social institutions like- parental control, familial relation, religion, etc (Shaakir, 2016).

\section{b. Empirical Review:}

This section highlights key readings relevant to the study. In Bangladesh Transgender community has been a part of our social system for a long time. Still their livelihoods are prorated into two major livelihoods. First one is the traditional system likecollect money from the people, shops and markets. And the other one is very few marginal jobs in the economic system. There are a very few transgender people are established. The reasons behind this situation are not unknown. There is a social constructed idea that these transgender people are only capable of doing such activities like- singing, dancing and collecting money. Even when they are capable of doing something else better than only collecting money or the other two, most of the time they are ignored from to take the opportunity. As a result they are being frustrated and trying their best do something else they have the easy access like- prostitution, drug addiction, drug trafficking, fraud, black marketing, extortion and various other various criminal activities (Orthy, 2018). The findings are consistent with other studies among MSM in India that have shown a high prevalence of depression or frustration (Logie et al., 2012), sexual harassment and violence (Newman et al., 2008), and alcohol use (Yadav et al., 2014).

Internationally, methamphetamine use is prevalent among males who have sex interest with males (MSM) and transgender women (hijra), with studies showing its association with risky sexual behaviors leading to HIV transmission that raises the crime rate as they give up their hope for the future (Khan et al., 2018). Transgender (or Trans) men have a male gender identity that does not conform to the female sex declared at birth. There is a dearth of information on the experience of such men in Bangladesh. Many of the Trans men Human Rights Watch initially reached out to choose not to be interviewed because of security concerns and those were interviewed requested anonymity. The researchers have used pseudonyms and withheld information about the ages and the exact locations of the interviews (HRW, 2018).

A study from the Naz Foundation International (NFI) reports on the high levels of sexual violence, marginalization and stigma experienced by males who have sex interest with males (MSM) in India and Bangladesh. The report finds that the primary cause of this violence is cultural gender norms rather than sexual identity, since those MSM who identify as Kothi (feminine men) are most at risk. Stigmatization reduces the educational and other opportunities available to feminine MSM and the resulting poverty leaves some MSM dependent on sex work and vulnerable to abuse and HIV infection. The study also reports that this group experiences high levels of discrimination in accessing services, and high levels of harassment, including sexual violence and abasement from the police (Khan et al., 2005).

Interestingly, homosexuality was usually associated in colonial discourse with the "martial races", not with "effeminate" Bengalis. Yet the colonizers perceived the figure of the hijras as effeminate, sexually "deviant" and "impotent" as a figure of failed masculinity (Hinchy, 2014). 
In order to better understand the critical implications of drag in issues of political and social resistance, one need to review gender and gendering as intellectual sites where the power dynamic of male/female, straight/gay, superior/inferior, original/duplicate is at work. In other words, all contemporary gender relationships are hegemonically structured around the possession of power. A part from the play and performance that one links to drag, we must also relocate drag in a broader context of the power problematic. I believe that at a non-complex level, drag relies heavily on the ability to shock and scandalize.

The techniques for resisting pre-given identity limits used by drag queens mostly consist of an exaggeration and a deliberate overplay of the "feminine." This can certainly be read as an instrument of "male" power so that men can pose as, and seemingly be, "better" women than women themselves. Drag may tell us how gendered identity is constructed by cultural and social conditioning but it also paradoxically often relegitimates gender as an essential category with its focus on exaggerated forms of the feminine (Bakshi, 2004). Drag, as Schacht argues, is often a form of "homosexual embodiment of the heterosexual," where by a drag performance often fixes and reinstates the gender binary rather than exposing it. Read in this way drag shows "become wholly dependent on the audience's normative expectations about their gender and sexuality" and are "frequently more reflective than transgressive of the dominant culture's ideals of gender and sexuality" (Schacht, 2002).

By hook or by crook the transgender people get them benefitted. They force the general people to take their blessings at a high price at different occasions or ceremonies. This sort of activities seems to the public as burden and they become angry with the transgender people that raise the conflict of interest among them (Whitehead, 1998). Regarding high-risk sexual behaviors', about $70 \%$ of unmarried drug users had been sexually active within the previous month. Over $70 \%$ of all drug users reported sex with sex workers. A noticeable observation was that there was little difference between condom use practices among current IDUs from intervention and non-intervention sites. It was also noted that a high proportion of drug users (over 90\%) were unaware of the risk of HIV/AIDS through male-to-male sex or sex with 'hijras' (transgender). This is really a great concerning issue that only $10 \%$ of the male respondents reported sex with male/hijras and use condoms in those situations, that was really very low (UNODC, 2005).

Section 377 is still in effect throughout India with similar versions of the code in existence among other former British colonies. "Unnatural offences" were defined as crimes using the following definitionWhoever voluntarily has carnal intercourse with any man, woman or animal against the order of nature shall be punished with imprisonment for life or with imprisonment of either description for term which may extend to ten years, and shall also be liable to fine. While the definition of what is "unnatural" will subjectively vary, the legislation implied that hijra, gay men and transgender persons were considered criminals and their behavior legally punishable (Lawyers Collective, 2017). The number of crime singling out among transgender and gender nonconforming people also spiked by $41 \%$ to previous year (Kaleem, 2019).

In Bangladesh, there are a number of groups those who are involved in different criminal activities likethey are forcefully converting man into hijras those who have female appearance in male body and financially insolvent. As a result they are not real hijra by birth but transplanted by some greedy people in the society those who are remain in dark side and doing their illegal business to fulfill their bad intention (Khatun, 2017). Most of the hijras are living on their day to day earnings from the market or houses what is known as 'tola' and to collect this sort of earnings they are using their parading effeminacy that seems to others as crime (Mishu, 2015). Many of the hijras are not real but they are continuing their illegal collection like as hijras in the city that raises crime rate in Bangladesh. As it is easy to earn money with less effort, so many frauds are interested to be involved in such criminal activities especially those who are playing role as Gurumas in Dhaka city (Talash Crime Hijra Episode, 2016). 


\section{METHODOLOGY:}

The study has applied descriptive research design with qualitative study. Most of the data was collected from secondary sources like- scholarly articles, newspapers, several online YouTube channels, FBI reports, Bangladesh Police Discipline Security Progress reports and so on.

Few data was also collected from primary sources like- directly interviewing the transgender people who have sufficient knowledge about criminal activities that are occurring at present time in Bangladesh. In case of interviewing, purposive sampling method was used to select the transgender people as sample size.

\section{FINFINGS AND DISCUSSION:}

After reviewing and analyzing the relevant literature of the study the researchers have divided the discussion and findings part into three main categories. Firstly, what are the criminal activities done by the transgender people in Bangladesh? Secondly, what are the reasons behind their involvement in such criminal activities? Thirdly, what are the consequences or effects of such criminal or offensive activities in increasing crime rate in Bangladesh?

\section{Criminal activities done by the transgender people (Hijras) in Bangladesh}

According to Bangladesh Police there are mainly two types of crimes occurred by the people like- heinous and non-heinous crimes. Both types have many subtypes but all the criminal activities are not done by the transgender or hijra people in Bangladesh. From the previous study of relevant literature, interviewing some transgender people and investigating crime reports it can be easily made a chart of criminal activities that are done by the hijras or they are involved in Bangladesh. They are the followings:

$>$ Mass disturbs

$>$ Disorganized behave to common people to give them money as 'tola'

$>$ Sexual crime

$>$ Breaking of drug related law
$>$ Flattery

$>$ Gambling

$>$ Terrorism and torture to subordinates

$>$ Others

\section{The reasons behind their involvement in such criminal activities}

Crime can be defined in many ways. Different societies may also choose to define crimes in different way. However, in general crime can be defined simply as the breach of laws or ordinances that are imposed by the ruling authority of the state or country. There are many reasons for committing crimes and various studies are conducted all over the world to understand and bring down criminal activities. It is a constant endeavor of governments and policing organizations all over the world to bring down crime rates so that the world becomes a safer place to live in (Shaakir, 2016). Bangladesh is not an exception in case of committing crime; here the various groups are involved in criminal activities and transgender people or hijras are the group of people among whose many of them are involved in various criminal activities. But the fact is that there are some reasons behind their criminal or offensive activities. On the basis of findings from various literatures relevant to the study the researchers have found some possible reasons that are closely related to their criminal activities in Bangladesh. They are discussed in the following way:

$>$ Lack of Employment Opportunity: In Bangladesh still now there are no specific fields for transgender people to be employed. A step was taken to employ them in Traffic police sector but not yet implemented. The other sectors ignoring to get them as employees. Though at present some of the institution are coming forefront to enroll them in several jobs but these are enough for them. Since they are human being they need money to 
support their day to day expenses. As a result they are involving in several criminal activities as they get soon as their demand to sustain in the society or communities.

$>$ Poverty: Poverty is a great problem for Bangladeshi people. Most of the people live in hand to mouth. They have no sufficient wealth to meet up their basic needs. As for this they are involving several criminal activities and Transgender people or hijras are not the exception.

> Parental and Social Relations: Transgender people or hijras are exploited in the family and society. They are neglected by their parents also though they are the children of their parents. When the behaviors of such transgender people are disclosed they become to lose their expectation from their family or society. Parents feel embarrass to identify them as their children in the society. As a result they are throughout from their home and need to search a new world where they feel comfort. This sort of relation pushes them to involve in criminal activities.

$>$ Influences of Guruma have to hold their position: When the transgender people come out from their family they get help or support from the gurumas of various transgender groups. Since they live in a different community they need to obey the bosses (Guruma) in their communities. The gurumas try to control them by imposing various rules on them to hold their position in the community. These sorts of influences sometimes instigate them to involve in criminal activities.

> Racism: Transgender people are greatly faced racism in the society. When they see they are not getting equal rights as of others enjoying they are being frustrated and get involved in several criminal activities those are harmful for the society.

$>$ Lack of Education: Our education system is not out of the framework of our social system. As a result transgender people get embarrassed by others in the educational institution and maximum time they give up their hope to be educated. Since they are not educated enough they can't try for a good job and remain poor. This system occurs simultaneously and that is why to come back from the situation they are mostly involved in several criminal activities.

$>$ Sexual Needs: Most of the case in our country transgender people involved in prostitution and it is offensive by laws in Bangladesh. Since transgender people are not male or female but the other that is why they can't enjoy a happy married life like us though they have some sex oriented physiological needs. And to meet up their physical demands they are involving such criminal activities like prostitution that meet up their both demands (physical and financial). Many of the transgender people feel prostitution better than beg alms as they are using their body to earn something that is prestigious than to get help from the others.

$>$ Depression and other social and mental disorders: From the various study it is clear that the mental state of transgender people is not stable as normal human being. Most of the times they feel shy as for their physical and mental condition that instigate them to be more depressed. These accumulate depression encourage them to be drug addicted and alcoholic and final in criminal or offensive activities. 
Drugs and Alcohol: When someone is addicted to drugs and alcohol he/she has no common sense to apply their good feelings. They become arrogant and they don't feel they are doing such offensive or criminal activities.

$>$ Cross border linkage: From the study researchers have confirmed that many of the transgender people have no passport but they are maintaining cross border linkage with Indian or other countries transgender people. They go outside of the country without any passport but using their parading effeminacy to cross the border to save money that is illegal by laws in our country.

$>$ Others: Sometime the other causes may influence them to be involved in criminal activities like- internal conflict among the group members, political conflict, heredity wealth conflicts among brothers and sisters, unfair rulings by the superiors or gurumas, etc.

3. The consequences or effects of such criminal activities in increasing crime rate in Bangladesh

Bangladesh is a peace loving country. Everybody here wants to live in peace. But recent time its status is changing for several criminal activities around the country. The researcher's hypothecation is that there is a relationship between the changing crime situation and the parading effeminacy of transgender people in Bangladesh. Crime has great impacts on all aspects of people's life. It hampers the general life of people in the society as it is a major part of every society. Its costs and effects just touch everyone to some extent. The costs and effects are widely various types. In addition, some costs are short-term while others lasted for a lifetime. Of course the ultimate cost is the loss of life. Other costs to victims can be included as property losses, medical costs and loss of income. Since the relevant study (scholarly articles, newspapers, several online YouTube channels, FBI reports, Bangladesh Police Discipline Security Progress reports and so on) indicates that the transgender or hijras in Bangladesh are involved in several criminal activities that raises the level of crime rate in world crime index record book. The major consequences or effects of such criminal activities by the transgender people in Bangladesh are pointed as below:

\section{Increasing overall Crime rate:} According to FBI crime reports 2018 in America $57.5 \%$ were influenced by a race/ethnicity/ancestry bias, $20.2 \%$ were motivated by religious bias, $17 \%$ were influenced by sexual-orientation bias, $2.4 \%$ were influenced by genderidentity bias, $2.3 \%$ were influenced by disability bias and $0.7 \%$ were influenced by gender bias (Donaghue, 2019). Bangladesh is not an exception. The same scenario existing here. Day by day the rate of crime is being increased and for this increasing crime rate transgender people have a great involvement. If it is not possible to stop doing such criminal activities then the situation will go out of range to control.

$>$ Collapse Law and Order Situation in the country: transgender people are also part and parcel of our society and they are also bound to obey the law and order imposed by the state. But if they become arrogant and get involved in various criminal activities then the entire law and order situation of the country will collapse.

$>$ Increased Social Imbalances': Almighty Allah create all beings in the world in balanced way. So, if any abnormal situation is occurred by the marginalized group of people for their unwanted behaviors then the social 
imbalance will increase and the world will be a dark place to live in.

$>$ Increasing Political Corruption and Instability: If the transgender people becoming more engaged in criminal activities then the political leaders in this country will try to use them for their own benefits that will finally increase the political corruption and instability of the country.

$>$ Increased Familial Disorder when Decreased Family Status: If the transgender member of the family engaged in such criminal activities then it will increase familial disorder and decrease the status of the family in the society.

\section{CONCLUSION:}

The transgender or hijra subculture remains one of the most marginalized and violated minority groups in Bangladesh. Though, with recent legislative decision in Bangladesh, the group has gained their legal recognition as third gender in various government or non-government official records or documents. The transgender people are now allowed to conform in any formal and official documents within the nation, listed 'hijra' as their gender (Stenqvist, 2015). The only official recognition is not enough for them to change their state of condition if we are able to change their socio economic condition. Still now the government has negligence to establish a secured rule for them in their community or society. They have no secured job they can continue. From all aspects in the society they are neglected and they are not treated as same as others. As it is continuing for longer period then all endeavors will not effective for the change of life and socio economic condition. As a result their involvement in such criminal activities will difficult to stop in the country and finally the overall crime rate will go high.

The word 'hijra' often used to indicate the transgender people is a social construct not a biological construct (Jahan, 2016). So we have to think that they are also human being with different category. They need more emphasis to build social and familial relationship with others in the family or society. They need more scope to educate them to be efficient and competent enough to beat the challenges they are facing their day to day life. If it is possible to give them proper education and financial security at their old age time they will feel confident and will encourage to involve in social activities rather than criminal or offensive activities. Finally, the society as well as the country they are involved with will be a good place to live in peace.

\section{ACKNOWLEDGEMENT:}

The researcher greatly obliged his supervisor for his kind supervision, intellectual motivation, valuable advice and continuous guidance.

\section{CONFLICTS OF INTEREST:}

The author declared no potential conflicts of the interest with respect to the research study.

\section{REFERENCES:}

1) Ahmed, S. (2017). Recognition of 'Hijra' as Third Gender in Bangladesh. Bringing changes. Improving lives. Keeping promises.

http://www.bandhu-bd.org/

2) Altilio, T. \& Otis-Green, S., (2011). Oxford Textbook of Palliative Social Work. Oxford University Press. p. 380. ISBN 978-01998 38271. Archived from the original on December 1, 2016. Retrieved April 12, 2016. Transgender is an umbrella term for people whose gender identity and/or gender expression differs from the sex they were assigned at birth (Gay and Lesbian Alliance against Defamation [GLAAD], 2007).

3) Bakshi, S. (2004). A Comparative Analysis of Hijras and Drag Queens: The Subversive Possibilities and Limits of Parading Effeminacy and Negotiating Masculinity, Journal of Homosexuality, 46(3), 211-223. http://dx.doi.org/10.1300/J082v46n03_13

4) BBC NEWS. (2019). Transgender hate crimes recorded by police go up to $81 \%$. BBC NEWS, 2019. https://www.bbc.com/news/uk-48756370

5) Crime Index. (2019). Crime Index for country 2019 Mid Year. NUMBEO.

https://www.numbeo.com/crime/rankings by cou ntry.jsp 
6) Donaghue, E., (2019). FBI: Hate crime murders hit record in 2018; crimes targeting transgender people soar. CBS News. NOVEMBER 12, 2019 /8:31 PM/CBS NEWS.

7) Elizabeth A. M., (2003). Oxford Dictionary of Law (7ed.). Oxford: Oxford University Press. ISBN 978-0-19-860756-4.

8) Elizabeth A. M., (2003). Oxford Dictionary of Law (7ed.). Oxford: Oxford University Press. ISBN 978-0-19-860756-4.

9) Farmer, L., (2008). "Crime, definitions of", in Cane and Conoghan (editors), The New Oxford Companion to Law, Oxford University Press, 2008 (ISBN 978-0-19-929054-3), p. 263, (Google Books).

10) Forsyth, C. J. \& Copes, H., (2014). Transgender is an umbrella term for people whose gender identities, gender expressions, and/or behaviors are different from those culturally associated with the sex to which they were assigned at birth. Encyclopedia of Social Deviance. Sage Publications. p. 740. ISBN 978-1483364698. Archived from the original on December 1, 2016. Retrieved April 12, 2016

11) Hinchy, J. (2014). Obscenity, Moral Contagion and Masculinity: Hijras in Public Space in Colonial North India. Asian Studies Review, 2014, 38(2), 274-294. http://dx.doi.org/10.1080/10357823.2014.901298

12) Hossain MR, Khatun S, and Rashid MA. (2019). Present Status of Information and Internet Services in Union Council of Madhukhali Upazila: A Case Study, Br. J. Arts Humanit., 1(6), 35-44.

https://doi.org/10.34104/bjah.019.35044

13) Human Rights Watch. (2018). Bangladesh: Transgender Men Fear for Their Safety. Transgender Men Face Threats and Widespread Discrimination. Human Rights watch, Bangladesh Perspective, January 19, 2018

14) Jahan, I., (2016). Review of me Laxmi, me Hijra: an Autobiography of Laxminarayan Tripathi, Translated by R. Raj Rao and P. G. Jshi. LangLit, 2 (3), February, 2016. ISSN 23495189. Website: http://www.langlit.org/

15) Kaleem, J. (2019). Latinos and transgender people see big increases in hate crimes, FBI reports. Los Angeles Times, NOV. 12, 2019. https://www.latimes.com/worldnation/story/201911-12/hate-crimes-fbi-2018

16) Khan, S., Bondyopadhyay, A., and Mulji, K., (2005). From the Front Line: The Impact of Social, Legal and Judicial Impediments to Sexual Health Promotion, and HIV and AIDS Related Care and Support for Males Who Have Sex with Males in Bangladesh and India. Lucknow, India: Naz Foundation International.

17) Khan, S.I., Khan, M.N.M., Hasan, A.M.R., Irfan, S.D., Horng, L.M.S., Chowdhury, E.I. \& Azim, T., (2018). Understanding the reasons for using methamphetamine by sexual minority people in Dhaka, Bangladesh. International Journal of Drug Policy, 73, November 2018, 64-71.

18) Khatun, F. (2017). হিজড়া যৌনাঙ্গ নিয়ে রাস্তা ঘাটে অনৈতিক কাজ! HIJRA BANGLADESH. Investigation 360 degree, Jamuna TV. Retrieved from:

https://www.youtube.com/watch?v=duSHFWV1z $\underline{0 \mathrm{M}}$

19) Lawyers Collective (2017). Retrieved Feb. 19, 2017 from: http://www.lawyerscollective.org/ vulnerable-communities/lgbt/section-377.html

20) Logie, C. H., Newman, P. A., Chakrapani, V., \& Shunmugam, M., (2012). Adapting the Minority Stress Model: Associations between gender nonconformity stigma, HIV-related stigma and depression among men who have sex with men in South India. Social Science and Medicine, 74(8), 1261-1268.

https://doi.org/10.1016/j.socscimed. 2012.01.008

21) Mishu, M. (2015). Hijra (Hermaphrodite) Community in Bangladesh: Series Report of Mahfuz Mishu on Jamuna TV. Retrieved from: https://www.youtube.com/watch?v=2PaJEm0K44

22) Newman, P. A., Chakrapani, V., Cook, C., Shunmugam, M., \& Kakinami, L. (2008). Correlates of paid sex among men who have sex with men in Chennai, India. Sexually Transmitted Infections, 84(6), 434-438.

23) Orthy, S. R. K., (2018). Transgender Community in Bangladesh: A study on resistance to structural violence for a better livelihood. https://www.academia.edu/39366946/Transgender 
_Community_in_Bangladesh_A_study_on_resista nce to structural violence for a better_livelihoo $\underline{\mathrm{d}}$

24) Oxford English Dictionary. (2009). "Crime". Oxford English Dictionary Second Edition on CD-ROM. Oxford: Oxford University Press. 2009.

25) Parvez MS, Rahaman MA, Fatema K, and Mondal DR. (2019). Impact of Social Networking Sites on the Interpersonal Relationship among Teenager: A Sociological Analysis in the District of Bagerhat. Br. J. Arts Humanit., 1(5), 14-27.

https://doi.org/10.34104/bjah.019.1427

26) Schacht, S. P. (2002). Four renditions of doing female drag: Feminine appearing conceptual variations of a masculine theme. Advances in Gender Research, 6, 157-180.

27) Shaakir, A. (2016). Criminal Activities in Bangladesh: Causes and Consequences. Institute of social welfare and Research, University of Dhaka. January 8, 2016. Retrieved from: https://Transgender\%20in\%20offensive\%20activit ies/Criminal_Activities_in_Bangladesh_Causes.pd $\underline{\mathrm{f}}$

28) Stenqvist, T., (2015). The social struggle of being HIJRA in Bangladesh - cultural aspiration between inclusion and illegitimacy. Communication for Development, Malmö University. Spring 2015. Submission date: 7th of January 2015.

29) Talash Crime Hijra Episode. (2016). Talash
Crime Hijra Episode 1 বাংলাদেশের হিজরা. Independent TV, 2016. Retrieved from: https://www.youtube.com/watch?v=qESHCRAYy A

30) UNODC. (2005). Bangladesh- United Nations Office on Drugs and Crimes, South-Asian Regional Profile.

https://www.unodc.org/pdf/india/publications/sout h_Asia_Regional_Profile_Sept_2005/08_banglade $\underline{\text { sh.pdf }}$

31) Wallen, J., (2019). Transgender community in Bangladesh finally granted full voting rights. The Telegraph.

https://www.telegraph.co.uk/globalhealth/climateand-people/transgender-community/bangladeshfinally-granted-full-voting/

32) Whitehead, A. (1998). The hijras' blessing. BBC News Online, August 16, 1998. Published at Sunday 13:58 GMT 14:58 UK.

33) Wikipedia. (2019). Crime in Bangladesh. https://en.wikipedia.org/wiki/Crime_in_Banglades $\underline{\mathrm{h}}$

34) Yadav, D., Chakrapani, V., Goswami, P., Ramanathan, S., Ramakrishnan, L., George, B., Paranjape, R. S., (2014). Association between alcohol use and HIV-related sexual risk behaviors among men who have sex with men (MSM): Findings from a multi-site biobehavioral survey in India. AIDS and Behavior, 18(7), 1330-1338. https://doi.org/10.1007/s10461-014-0699-x

Citation: Sema SA. (2019). The subversive use of parading effeminacy by transgender people in increasing crime rate in Bangladesh: a study on several investigating crime reports, Br. J. Arts Humanit., 1(6), 45-55. https://doi.org/10.34104/bjah.019.045055 क्ष क 